\title{
Linguistic Constructions of Appraisal in the Novel The Picture Of Dorian Gray and its Brazilian Translation and Adaptations: an Exploratory Analysis
}

\section{Construções linguísticas de avaliatividade no romance The Picture of Dorian Gray e em sua tradução e adaptaçóes para o português brasileiro: uma análise exploratória}

\author{
Adail Sebastião Rodrigues-Júnior* \\ UFOP/PUC-SP/CNPq \\ Mariana - Minas Gerais / Brasil \\ Leila Barbara** \\ PUC-SP/CNPq \\ São Paulo - São Paulo / Brasil
}

\begin{abstract}
This paper aims to investigate how the linguistic elements of appraisal construe the evaluative representations of (gay) literary characters in the novel The Picture of Dorian Gray and in its Brazilian translation and adaptations. The centrality of the investigation is the narrator's voice, imprinted in the projecting verbal processes and the content of the message that constitute either the narrative point of view or the dialogues performed by the characters. To pursue this objective, we have adopted Martin's and White's (2005) appraisal model, employed to uncover linguistic resources that express attitudes towards events and people, with more or less intensity or graduation, and with different forms of commitment or engagement. The software program WordSmith Tools, more specifically the Aligner utility, served as the basis for selecting and organizing some extracts of the original novel comparatively with the same extracts of the translation and adaptations. The analyses have indicated that the narrator offered the vast majority of evaluative descriptions of femininity, which points to the importance of narrative point of view for the construing of the plot and for the establishment of ideological standpoints. The discussion has also shown several differences of evaluative
\end{abstract}

\footnotetext{
* adail.sebastiao@gmail.com

**1barbara@uol.com.br
} 
linguistic choices in the translation and adaptations when compared to the original, demonstrating that the corpora do not fall within the boundaries of a strict linguistic correspondence, but rather within the limits of text recreation or rewriting. KEYWORDS: The Picture of Dorian Gray; translation; adaptation; SystemicFunctional Linguistics; appraisal.

RESUMO: Este artigo tem como objetivo investigar como os elementos linguísticos de avaliatividade constroem os personagens (gays) no romance The Picture of Dorian Gray e em sua tradução e adaptações para o português brasileiro. A base da análise localiza-se na voz narrativa, presente nos processos verbais projetantes e no conteúdo da mensagem que constitui tanto o ponto de vista narrativo quanto os diálogos dos personagens. Para a realização desse objetivo, adotamos o modelo de avaliatividade de Martin e White (2005), empregado para revelar os recursos linguísticos que expressam atitude para com os eventos e as pessoas, com maior ou menor intensidade ou gradação, e com formas diferentes de comprometimento ou engajamento. O programa computacional WordSmith Tools, especificamente o utilitário Aligner, foi usado para selecionar e organizar alguns excertos da obra original em comparação com os mesmos excertos da tradução e das adaptações. As análises indicaram que o narrador foi o responsável por oferecer a maioria das descriçōes avaliativas de feminilidade, indicando a importância do ponto de vista narrativo para a construção de significados do enredo e para o estabelecimento de ideologias. A discussão também mostrou que várias diferenças de escolhas linguísticas de avaliação na tradução e nas adaptações, quando comparadas ao original, revelam que os dados encontram-se nos limites da criação textual ou reescrita, e não nos limites da correspondência estrita.

PALAVRAS-CHAVE: O Retrato de Dorian Gray; tradução; adaptação; Linguística Sistêmico-Funcional; avaliatividade.

\section{Aim of the study}

This paper aims to investigate how the linguistic elements of appraisal (MARTIN, 1999; MARTIN; ROSE, 2003, 2007; MARTIN; WHITE, 2005) construe $^{2}$ the evaluative representations of (gay) literary characters in both the

\footnotetext{
${ }^{1}$ The authors would like to thank The National Counsel of Technological and Scientific Development (CNPq/Brazil), process number 500854/2011-4, for sponsoring this research. They are also grateful to Orlando Vian Jr. (Universidade Federal do Rio Grande do Norte, Brazil) and Karen Laing-Urbina (College of Southern Nevada, USA) for the invaluable suggestions on an earlier draft of this paper.

2 The idea lying behind the notion of construing was satisfactorily explained by Hunston and Thompson (1999, p. 142): "expressing and simultaneously "creating". Since we will be using this concept throughout the paper, we considered it relevant to provide its meaning at the outset.
} 
novel The Picture of Dorian Gray and in its Brazilian translation and adaptations. Martin and Rose claim that "appraisal is concerned with evaluation: the kinds of attitudes that are negotiated in a text, the strength of the feelings involved and the ways in which values are sourced and readers aligned" (2003, p. 22).

Moreover, in this paper, we agree that verbal process are the 'engine room' for narrative construction and consequently for the creation of discourse events in literary texts. The notion of discourse event that we adopt in this study stems from the following passage:

The meaning of an event or of a single utterance is only partly accounted for by its formal features (that is, by the 'direct meaning' of the words used). The social significance of discourse, if we define it simply as language-in-use, lies in the relationship between linguistic meanings and the wider context (i.e., the social, cultural, economic, demographic and other characteristics of the communicative event) in which interaction takes place- (JAWORSKI; COUPLAND, 2006, p.11).

In addition, we also consider verbal processes as discursive elements that open various possibilities for understanding the plot and how its characters establish connections and interact with each other. This interactive phenomenon reveals the linguistic constructions by which characters interpret the fictional experiences surrounding them, as well as provides the space for identifying some features of narrative point of view when the narrator gives specific semantic contours to characters or Sayers (cf. SIMPSON, 1993)., we also aim to give special attention to sources of attitudes (voice), or "who are the evaluations coming from" (MARTIN; ROSE, 2003, p. 44), since the narrator is the most prominent element in the plot responsible for evaluating the characters and the discourse events wherein they construe their fictional realities.

To uncover some of these features, we consider that a linguistic approach concerned with evaluation (MARTIN; WHITE, 2005) provides effective tools to show how characters in literary discourses are either shaped or represented, especially given that the novel construes a very specific reality 'semiotically', as the data analyzed encompass a wide range of controversial discourses, most of which are related to homosexuality and prejudice. As we are dealing with original and translated texts, the discussion will also shed light on the concept of equivalence, based primarily on Yallop (2001), in the context of linguistic-oriented translations of gay fiction.

To achieve our aim, we provide a description of the corpora, briefly discuss the place of gayness issues in Translation Studies, present the theory 
underpinning the study and the methodological procedures for selecting the data, carry out the analyses, and draw some preliminary conclusions.

\section{Corpora description}

Oscar Wilde's The Picture of Dorian Gray, one of his masterpieces, written throughout his intense and rich literary life, became famous for its 'fictitious' context and for revealing his homosexual tendencies in the closing period of the Victorian age in England and Ireland (cf. PIRES, 2005; PURCHASE, 2006; SCHIFFER, 2010). As expressed in Mighall

Characteristically, [the novel] was a succès de scandale. His novel provoked, at least in Britain, an outraged response from many reviewers, providing a foretaste of the treatment he would receive five years later when what some believed they had found represented in Dorian Gray (outlawed passions and 'unspeakable' acts) were revealed to be part of its author's life. Indeed, Wilde's novel, or at least the more 'candid' first version, was used by opposing counsel in the first two of his three trials in an attempt to prove that he was guilty of 'a certain tendency' believed to be represented in Dorian Gray (2003, p. ix).

Distinguishing features of the novel are Wilde's linguistic choices, which provide a moral critique of an age of restrictions and prejudices that pervaded most of the socio-semiotic environment of the time. Part of these choices will be thoroughly examined during the analyses.

In 1919, in an attempt to represent the exquisite beauty of the novel, João do Rio translated The Picture of Dorian Gray into Brazilian Portuguese. His aim was to make visible to the reader a literary masterpiece of the British belle époque, full of subtle nuances of dandyism and extravagant lifestyles (cf. FIGARI, 2007). João do Rio was also responsible for imprinting in Rio de Janeiro's society, between 1915 and 1921, the practice of dandyism, a particular aesthetic lifestyle common to aristocratic British and French people. Dandyism recognizes Oscar Wilde as its perfect icon, and João do Rio explicitly incorporated all the great elegance of this way of life. João do Rio's translation has been acclaimed the novel's best rendering ever made in the Brazilian Portuguese language.

Clarice Lispector's (1974) and Claudia Lopes's (1997) adaptations were also selected, as both can be viewed as authorial texts, given their free reinstantiation, even though both used the source text as a point of departure. This means that both Lispector and Lopes created new interpretive possibilities for the characters, giving rise to distinctive fictional aspects. Their writing styles 
made new scenes of interpretation visible, especially since the adapted versions presented the juvenile as their main readers, a kind of readership leading to the need for both reconfigurations as well as free versions of the original. Consequently, the adapted versions recreated the characters by omitting important details and behaviors belonging to them. The great majority of the details and behaviors are uncovered when we use the lens of the Appraisal model to explore the data.

\section{Gayness and linguistic-oriented Translation Studies}

Drawing on linguistic analysis of parody, Harvey (2000a) $)^{3}$ acknowledges that the use of $c a m p^{4}$ reinforces an ideological positioning against mainstream social categories of empowered heterosexual society pervaded by hegemonic discourses. Harvey's (2000b) analyses have revealed complex negotiations regarding the translation of camp style in France, which often minimized the discursive force of camp presented in the original. As an example of Harvey's position, we quote an extract (Example 1) of his analysis of the play Angels in America, a Gay Fantasia on National Themes; Part One: Millennium Approaches, written by Tony Kushner (1992, p. 76), and then compare it to the French translation (Example 2), which he also analyzed.

The scene is of two gay men, one named Belize and the other Louis. Belize is a black gay man who used to be a drag queen; Louis is Prior's boyfriend, who is in the hospital with an AIDS-related illness. Belize is Prior's close friend and lover. Louis and Belize are in a cafeteria discussing Prior's disease when Louis expresses an overwhelming sense of despair concerning Prior's fragile health.

\footnotetext{
${ }^{3}$ Keith Harvey is the most frequently quoted researcher in the area of Gay and Translations Studies, due to his adoption of a multidisciplinary approach (linguistics, discourse analysis, and pragmatics) in the investigation of translations of gay texts. There are, of course, other researchers involved in this specific issue, but they are mostly located within the fields of literary criticism and comparative literature.

4 For Harvey (2000a, p. 446): "camp is regularly attested in fictional representations of homosexual men's speech in French- and English-language texts from the 1940s to the present." He also reinforces that "the functions of camp are intimately bound up with the question of its evaluation" (Italicized in the original).
} 
Example 1:

BELIZE: [...] Look at that heavy sky out there...

LOUIS: Purple.

BELIZE: Purple? Boy, what kind of homosexual are you, anyway? That's not purple, Mary, that color up there is (Very grand) mauve.

(Source: HARVEY, 2000b, p. 155)

In addition to relating to the common stereotype of gays as hairdressers and interior designers, the adjective mauve holds what Harvey calls "subcultural investment" (2000b, p. 155), a kind of discursive power that points to a commitment to homosexual ideology as a value-laden manifestation of gayness. In other words, at the moment Belize questioned Louis's gay identity, by means of the problematic use of the adjective purple instead of mauve, he has also reaffirmed that Louis did in fact belong to that community and should therefore be aware of the political suggestion of the wrong use of that word.

In the French translation (Example 2), Harvey (2000b) identifies a curious phenomenon, this time not related to the complexity of mauve as a gay-oriented, politically-driven, commitment. Due to the influence of Enlightenment thinking, Harvey posits that gay literature has won reluctant acceptance in France, even from French authors whose main writing concern is gay fiction as a kind of lifestyle.

Example 2:

BELIZE: [...] Regarde comme le ciel est lourd là-haut...

LOUIS: Poupre.

BELIZE: Poupre? Mais, enfin, quell genre d'homosexuel es-tu? Ça ce n'est pas du poupre, Josiane, cette couleur là-aut (Très grandiose) c'est du mauve. (Source: HARVEY, 2000b, p. 156)

This time Harvey (2000b) disregards the underlying tension of whether purple or mauve should actually be used interchangeably in the analyzed scene in order to turn his attention to another adjective, Josiane as the French translation of Mary. According to Harvey (2000b), Mary is a gay idiom in American culture, usually referred to a gay man who "goes regularly to the gym to bodybuild" (p. 157), whereas Josiane "evokes several stereotypical ideas: a working class woman, loudmouthed and probably coarse, possibly from an older generation” (p. 158). The impact of the use of the adjective Josiane in the target-text reader leads to a heterosexual discursive construction of the gay character as a 'woman' with specificities that were established by the generally heterosexual and hegemonic French society. This word choice provokes a kind of absence of meaning for the 
target-reader, because the functional use of Josiane does not set off resonances for gay readers. On the other hand, the use of the name Mary as an adjective, regarded as a gay idiom, testifies to the struggles homosexual communities in the US have been engaged in and the rapid advances these struggles are making. However the impact of this adjective in French culture, the choice of Josiane-, diminishes its force, as it represents the other, in the sense of otherness, from a heterosexual and biased standpoint.

Harvey's examples illustrate the importance of instantiating the appropriate vocabulary to portray a fictional or, for that matter, real personality, in this case the choice of lexical items to fit the contexts of culture and situation (HALLIDAY; MATTHIESSEN, 2004, p. 19-31). This is the basis for the notion of 'evaluation' that we intend to reinforce in the remainder of this paper. That is, in addition to emphasizing the burden that such descriptors, such as purple and mauve, Mary and Josiane, carry, we also consider that a linguistic approach concerned with evaluation (appraisal) provides effective tools to uncover how characters in literary discourses are both shaped and represented. The quotation below helps stress the importance of evaluation for the question we are dealing with in this paper:

Within the more specialized area of literary stylistics, the investigation of point of view involves a number of linguistic features which indicate the source responsible for the text or segment (either a narrator or a character, or a blend of both); and the fact that both modality and appraisal must have a source - the person whose viewpoint is being expressed - makes them central to the investigation (...) (HUNSTON; THOMPSON, 1999, p. 5).

Hunston and Thompson's quotation touches on the aspect of narrative point of view, pointing out that the narrator's voice is one "important feature, which indicates the source responsible for the text or segment". Martin and Rose (2007) identify three linguistic mechanisms to pinpoint sources in texts: i) projection, by means of verbal processes and projected clauses, whereby additional sources of evaluation can be introduced in discourse; ii) modality, whose main objective is to unveil the appraiser's evaluation in terms of positive and negative poles, i.e. a "semantic space between yes and no" (MARTIN; ROSE, 2007, p. 53); and iii) concession, wherein conjunctions play a significant role, by which the speaker/writer acknowledges the addition of other voices to her/his own and the way speakers or writers track the listeners' or readers' expectancies towards what has been said or written. 
In the example below, extracted from the novel The Picture of Dorian Gray, we can identify sources in the text, by means of projecting verbs (replied), projected clauses (I know you will laugh at me and but I really can't exhibit it...), negation (I really can't...) and concession, which expresses a kind of 'counterexpectancy' by means of the use of but (but I really can't...):

\section{Example 3:}

'I know you will laugh at me,' he replied, 'but I really can't exhibit it. I have put too much of myself into it'.

Martin and Rose (2007) refer to the subsystem of source as engagement, a region of appraisal that looks at 'voices' as the manifestation of different and multiple stances of the speaker/writer towards listeners/readers. For the purposes of this paper, engagement is rather important, especially the subsystem of projection, whereby the narrator construes the plot as the text unfolds. In item 4, we will locate the subsystem of engagement in the overall picture of the Appraisal system.

\section{The Appraisal system}

The centrality of our investigation is the narrator's voice, imprinted in the projecting verbal processes and the content of the message that constitute either the narrative point of view or the dialogues performed by the characters. The axis is the verbal process and its projected dialogue. Surrounding the axis, we also find a multitude of clauses, the great majority of which are expansions ${ }^{5}$ and adjuncts, ${ }^{6}$ whose function is to present additional information, usually initiated by the main clause, and to embellish the discourse events informed by the narrator. Evaluative features, generally with the narrator as the main evaluator, pervade most of the linguistic constructions of the novel.

\footnotetext{
${ }^{5}$ According to Matthiessen, Teruya, and Lam, "expansion in the environment of clause complexes relates phenomena of the same order in which the secondary clause expands the primary clause by elaborating it, extending it or enhancing it. It includes the traditional categories of apposition, coordination and adverbial clauses:" (2010, p. 165).

6 "An adjunct is typically realized by an adverbial group or a prepositional phrase" (HALLIDAY; MATTHIESSEN, 2004, p. 124).
} 
As mentioned above, to analyze the evaluative complexities present in the novel, as well as its translation and adaptations, from a comparative perspective, we adopted Martin and White's (2005) Appraisal model to uncover the main aspects of this particular linguistic phenomenon in the corpora. We sketch this model very briefly here, since the reader can acquire a wider view of it by consulting the main references on the topic (see also MARTIN, 1999; MARTIN; ROSE, 2003, 2007).

Appraisal is but one slice of the interpersonal meanings explored by Halliday $(1985 ; 1994)$ and expanded in Halliday and Matthiessen (2004). Martin defines the guiding principle of appraisal as discourse semantics, "because a semantics of this kind focuses on text-size rather than clause-size meanings" (1992, p. 1). That is, it is not possible to measure the evaluative aspects of particular texts without taking into account how texts are organized, in terms of clause-paragraph-text interconnectedness, as well as the interrelationships between texts and major contexts of language-in-use. Martin and Rose (2007) advanced this approach by stressing that language both constitutes and is constituted by social realities. For these authors, discourse can be interpreted by means of meticulous linguistic analysis, by "treating discourse as more than words in clauses", in order to show how "semantic resources (...) lead us from one clause to another as a text unfolds". In a sense, they treat language from a discursive perspective, in which "discourse (...) is more than an incidental manifestation of social activity"; it is indeed part of a "constitutive role of meanings in social life" (2007, p.1).

Stemming from the essentials of Systemic-Functional Linguistics (SFL), the system devised by Martin and White (2005) allows for the understanding of the actual behavior of interpersonal and ideational items that vary from others not only in terms of their general ideational value, but mainly in terms of their interpersonal force or charge. Thus, appraisal is a model originated from careful studies on how speakers or writers employ linguistic resources to express attitudes towards events and people, with more or less intensity or graduation, and with different forms of commitment, or engagement.

Attitude is concerned with emotions, behaviors, usually as reactions to and evaluations of people's feelings and stances. Adjectives, modal adjuncts, circumstances of manner ${ }_{2}$ and the like form the general linguistic resources for identifying attitudes in texts. This system of meanings is divided into three domains: (i) referring to emotions and reactions to behaviors, information loaded in texts and phenomena of various types; affect is responsible for "registering positive and negative feelings" (MARTIN; WHITE, 2005, p. 42); 
(ii) concerning ethics and morals, Judgment is responsible for dealing with "attitudes towards behavior, which we admire or criticize, praise or condemn" (Ibid., p. 42); and (iii) dealing with aesthetics, appreciation is responsible for "evaluations of semiotic and natural phenomena" (Ibid., p. 43), most of which are assessments of things in general.

Engagement is concerned with identifying sources in discourse, or who is responsible for the content of discourse. This subsystem has to do with the speaker's or writer's commitment to what has been said or written. In this particular case, verbal processes, projections, modal adverbs, conjunctions, and the like constitute the general linguistic elements for pinpointing engagement in texts.

Graduation is one aspect of discourse capable of amplifying or downgrading the force of statements, making them more assertive or less incisive. It also helps locate categories within peripheral boundaries or centrality in an attempt to adjust the focus of specific limits. Adjectives of intensity and adverbs of degree form the general linguistic resources for graduation.

An example of how the Appraisal model is useful in understanding how characters construe specific fictional realities is presented in the example below, extracted from the novel The Picture of Dorian Gray:

\section{Example 4:}

'Yes; she is a peacock in everything but beauty,' said Lord Henry, pulling the daisy to bits with his long, nervous fingers.

In the subsystem of affect, the attributes peacock and beauty describe a specific woman, qualifying her in a negative manner. In terms of graduation, the expression in everything but beauty defines the boundaries of the attribution assigned to her: within the limits of weirdness and ugliness. In this very specific case, it is important to stress how the conjunction but imposes a certain counter-expectancy upon the reader, which helps the character to construe a specific picture: an ugly woman. Given that this is a projected clause, it is the narrator who informs the source of the speech: in this case, Lord Henry is recognized as the one who is responsible for the content of the message, or the one who is committed to the trustworthiness of the stated opinion. Concerning the narrative point of view, the narrator provides characters with very peculiar traits by evaluating their attitudes, judging their behavior ${ }_{2}$ or appreciating their lifestyles. This is clearly seen in the expansion pulling the daisy to bits with his long, nervous fingers, a kind of practice related to effeminate men, more tuned to dandyism practices at the time the novel was written. 
Likewise, the epithet nervous points to a character that is disquiet, anxious, most likely due to the situation he is taking part in. For the purposes of this study, expansions and other accompanying linguistic elements, such as adjuncts or circumstances, prove essential for unveiling the way the narrator evaluates the characters and provides them with very specific personality traits.

\section{Methodological procedures: Aligner utility}

The software program WordSmith Tools, more specifically, the Aligner utility, served as the basis for selecting and organizing the data. Concerning the guiding principle of discourse semantics, which orients the way in which we analyze the data, this paper focuses -the investigation on some extracts of the original novel in comparison with the same extracts of the translation and adaptations. The fundamentals for this selection are based on the nature of the adapted versions, as they are abridged texts which forced us to select clauses that appeared in both the original and the complete translation made by João do Rio. As we are not problematizing deliberate omissions in terms of full paragraphs in the adapted versions, a common aspect concerning adaptations, we searched for clauses that, to a certain extent, appeared in the data as a whole, or at least in the majority. The selection then generated 92 axes, ${ }^{7}$ comprised of projecting processes, projected clauses, and surrounding linguistic elements, such as expansions, adjuncts, and circumstances. Aligner displayed the clauses in parallel format, one below the other, in the following order: the first clause is an excerpt from the original novel; the second clause is an excerpt from the complete translated version; and the last two clauses are the excerpts from Lispector's and Lopes's adaptations, respectively. The ordering format followed the year in which each book was published, identified by the initials of the original text's author and of the translators. As such, OW was used for Oscar Wilde, which refers to the original, published in 1891; JR was adopted to represent João do Rio, referring to the complete translation, published in 1919; and LIS and LOP were assigned as the initials for Clarice Lispector and Claudia Lopes, respectively, indicating the adapted versions, published in 1974 and 1997.

After having analyzed the 92 axes, 10 were chosen as representative of the general linguistic patterns of appraisal in the original, as compared to the same patterns in JR's translation and LIS's and LOP's adaptations. These 10 axes will be thoroughly analyzed in item 6 .

${ }^{7}$ See item 4 for the definition of 'axis'. 


\section{Aligner-derived analyses}

The data was arranged based on the projecting verbs, taken as the fundamental axes that exemplifies who are saying what, how, and in what circumstances. In excerpt 1 , for example, the fundamental axis is the projecting verb said and the Sayer, Lord Henry; the projected clause It is your best work, Basil, the best thing you have ever done is the 'what' or the content of the saying phenomenon; finally, the modal adjunct languidly stands for the 'how', that is, the manner in which the Sayer behaved while expressing himself.

Excerpt 1:

\begin{tabular}{|l|l|l|l|}
\hline OW & $\begin{array}{l}\text { 'It is your best work, Basil, the best } \\
\text { thing you have ever done,' }\end{array}$ & said Lord Henry, & languidly. \\
\hline JR & $\begin{array}{l}\text { - Isso é tua melhor obra, Basil; a } \\
\text { melhor coisa que até hoje fizeste - }\end{array}$ & disse Lorde Henry & languidamente. \\
\hline LIS & $\begin{array}{l}\text { É a sua obra-prima, Basil. A melhor } \\
\text { coisa que você já fez - }\end{array}$ & disse lorde Henry. & Omission \\
\hline LOP & Omission & Omission & Omission \\
\hline
\end{tabular}

In excerpt 1 , it is clear that characters appreciate things (best work/best thing you have ever done) positively, and it seems that the narrator makes comments (affect) on the characters' behaviors (languidly). Both original and translated versions provide equivalent semantic information in terms of appreciation (melhor obralobra-prima/melhor coisa).

As to affect, LIS and LOP preferred not to translate languidly, sliding this experiential information into obscurity. On the other hand, JR has chosen a literal translation for the modal adjunct languidly, which raises questions concerning the appropriateness of his choice. That is, in the Oxford Dictionary, languid only means 'moving slowly in an elegant manner, not needing energy or effort'; in Collins Cobuild Dictionary, it means people who show 'little energy or interest and are very slow and casual in their movements'. In Houaiss, a dictionary of Brazilian Portuguese, languidez has several meanings: 'frouxidão' [loose-limbed (walk)], 'moleza' [slow (walk)], 'fraqueza' [weakness], 'apatia' [apathy], 'doçura' [kindness], 'brandura' [gentleness], 'voluptuosidade' [voluptuousness], etc. It seems that the translation did not retain all the semantic information of the original, ${ }^{8}$ leaving the contemporary ${ }^{9}$ target-language reader without a precise idea of the impacts of this way of walking to gay community members. ${ }^{10}$ By choosing the modal adjunct languidly, the narrator either makes remarks on the character's 
behavior or emphasizes a specific body movement. This semantic feature is somewhat lost in JR's translation.

Excerpt 2:

\begin{tabular}{|l|l|l|l|l|}
\hline OW & $\begin{array}{l}\text { 'I don't think } \\
\text { I will send it } \\
\text { anywhere,' }\end{array}$ & he answered, & $\begin{array}{l}\text { tossing his head back in } \\
\text { that odd way that used } \\
\text { to make his friends laugh } \\
\text { at him at Oxford. }\end{array}$ & $\begin{array}{l}\text { 'No: I won't } \\
\text { send it } \\
\text { anywhere. }\end{array}$ \\
\hline JR & $\begin{array}{l}\text { - Não pretendo } \\
\text { mandá-lo a parte } \\
\text { alguma - }\end{array}$ & $\begin{array}{l}\text { respondeu } \\
\text { o pintor, }\end{array}$ & $\begin{array}{l}\text { sacudindo a cabeça } \\
\text { de um modo singular, } \\
\text { que excitava o riso aos } \\
\text { seus amigos de Oxford. }\end{array}$ & $\begin{array}{l}\text { Não; não o } \\
\text { enviarei a } \\
\text { nenhuma } \\
\text { exposição. }\end{array}$ \\
\hline LIS & $\begin{array}{l}\text { - Não tenciono } \\
\text { mandá-lo a parte } \\
\text { alguma - }\end{array}$ & $\begin{array}{l}\text { respondeu } \\
\text { o artista. }\end{array}$ & Omission & Omission \\
\hline LOP & Omission & Omission & Omission & Omission \\
\hline
\end{tabular}

In excerpt 2, the expansion tossing his head back in that odd way that used to make his friends laugh at him at $O x$ ford expresses the narrator's reactions to the character's behavior (affect of the comment sort), as a way of evaluating the oddness and extravagance of his body movement. In this case, the narrator's point of view is instantiated by means of additional contours along the

8 'Frouxidão' and 'moleza' show certain proximity to the meaning of languidly, even though they are more akin to 'laziness' than to 'moving slowly in an elegant manner'. ${ }^{9}$ We say 'contemporary' because the meaning of languid, at the time Oscar Wilde wrote and published the novel, was, up to a certain point, similar to the meanings of languidez. The first edition of The Concise Oxford Dictionary (1911) brings the following synonyms for the word languid: 'inert', 'lacking vigor', 'indisposed to exertion', 'spiritless', 'apathetic', 'not vivid', 'dull', 'uninteresting', 'sluggish', 'slowmoving', 'faint', 'weak'. When the novel was published, the word languid stored multiple meanings and among them a kind of slow and mincing walk typical of dandies at the time. By having chosen this modal adjunct, Wilde probably wanted to camouflage this impact, especially after all the critiques his novel had received from severe as well as puritanical readers and critics of the late-Victorian society. ${ }^{10}$ We are not saying that 'straights' cannot behave this way; what we are stressing is that this kind of walk is somehow common among gays and probably has had such an impact at the time the novel was originally published. 
dialoguing axis, i.e. projecting verbs and projected clauses, which reveal the importance of clause complexes to the construing of characters' lifestyles and behaviors. JR's translation expresses the same meaning, which is omitted in the adapted versions.

Excerpt 3:

\begin{tabular}{|l|l|l|l|}
\hline OW & $\begin{array}{l}\text { 'I know you will } \\
\text { laugh at me,' }\end{array}$ & he replied, & $\begin{array}{l}\text { 'but I really can't exhibit it. } \\
\text { I have put too much of myself into it.' }\end{array}$ \\
\hline JR & $\begin{array}{l}\text { - Eu sei que rirás } \\
\text { de mim - }\end{array}$ & replicou o outro -, & $\begin{array}{l}\text { mas não posso realmente expô-lo. A essa } \\
\text { tela comuniquei muito de mim próprio. }\end{array}$ \\
\hline LIS & - Pode rir de mim - & $\begin{array}{l}\text { respondeu } \\
\text { o pintor. }\end{array}$ & $\begin{array}{l}\text { Mas não exporei o quadro. Coloquei } \\
\text { nele muito de meu eu. }\end{array}$ \\
\hline LOP & Omission & Omission & Omission \\
\hline
\end{tabular}

In excerpt 3, the projected clause I really can't exhibit it. I have put too much of myself into it (positive appreciation of the valuation sort) expresses a mixture of feelings. On the one hand, it positions Basil Hallward as the first appreciator of his own masterpiece, making a positive evaluation of it. On the other hand, the projected clause also locates the character within limits of insecurity or even desperation, since the idea of exposing his work of art frightens him, for it may reveal his inner feelings towards the person represented in the painting, in this case, Dorian Gray. This semantic characteristic, only approached from a discursive perspective, may well be a way of coming out, of hinting readers at Basil Hallward's most intriguing thoughts and eerie feelings. Thus, in addition to being considered a positive appreciation, the projected clause also incorporates features of affection which allude to insecurity (cf. MARTIN; WHITE, 2005, p. 50). This is outstanding because it reveals that Wilde chose specific linguistic expressions very carefully in order to uncover the characters' gayness and, likewise, to cause an impact on the (gay) reader of late-Victorian society. ${ }^{11}$ The translations tried to keep

${ }^{11}$ In this respect, it is worth noting Mighall's comment on Wilde's several revisions of the original manuscript of The Picture of Dorian Gray: "In the 1890 version there had been a much greater degree of physical intimacy between the principal male characters. In Chapter I, when Basil Hallward tells Lord Henry about his beautiful new friend, Henry lays 'his hand upon [Basil's] shoulder'. This seemingly innocent or inconsequential gesture Wilde chose to omit in 1891 [which was nonetheless recaptured in Mighall's 
this ideal by retaining the core of the original message. In the case of LOP's adaptation, this very important part of the novel is completely lost.

Excerpt 4:

\begin{tabular}{|l|l|l|l|}
\hline OW & $\begin{array}{l}\text { 'Dorian Gray? Is } \\
\text { that his name? }\end{array}$ & said Lord Henry, & $\begin{array}{l}\text { walking across the studio } \\
\text { towards Basil Hallward. }\end{array}$ \\
\hline JR & $\begin{array}{l}\text { - Dorian Gray? É o } \\
\text { nome dele? - }\end{array}$ & $\begin{array}{l}\text { perguntou Lorde } \\
\text { Henry, }\end{array}$ & $\begin{array}{l}\text { encaminhando-se para Basil } \\
\text { Hallward. }\end{array}$ \\
\hline LIS & $\begin{array}{l}\text { - Dorian Gray? É } \\
\text { assim que ele se chama? }\end{array}$ & $\begin{array}{l}\text { interrompeu lorde } \\
\text { Henry interessado, }\end{array}$ & aproximando-se do outro \\
\hline LOP & $\begin{array}{l}\text { - Dorian Gray? É } \\
\text { esse o nome dele? - }\end{array}$ & $\begin{array}{l}\text { perguntou Lorde } \\
\text { Henry, }\end{array}$ & $\begin{array}{l}\text { atravessando o estúdio } \\
\text { em direção a Basil Hallward. }\end{array}$ \\
\hline
\end{tabular}

To this point in the novel, the narrator continues to position himself towards the characters' feelings, emotions, behaviors, and the like. In excerpt 4 , what calls our attention is the additional element within the narrator's voice, representing an affect of the attributive sort, e.g. interessado (interested). Semantically speaking, this gives a different contour to the narrator's point of view in the adapted version written by LIS. In this respect, it is important to point out that, according to Yallop, "even where translators may seem to have moved away from a concern with accuracy and well into free adaptation, it is still possible to find points of correspondence" (2001, p. 231). One hypothesis for the addition of interessado may well be the verbal process choice interrompeu (interrupted), not an accurate translation for said. The use of interessado can be interpreted as an attempt to justify the interruption, showing that the character is curious about the information he is demanding from the artist, Basil Hallward. In this case, it is possible to say that LIS creatively rewrote the original, building a somewhat idealized experiential picture. This addition does not appear in the other translated versions.

edition, which we use as corpus]. Perhaps he felt he had gone too far, and could not risk being either too explicit or too ambiguous about these relationships" (2003, p. xvi). As far as appraisal is concerned, Wilde left some linguistic 'hints' in the 1891 version that uncover the 'unspeakable acts' his critics tried to veil. 
Excerpt 5:

\begin{tabular}{|l|l|l|l|l|}
\hline OW & 'Not at all', & $\begin{array}{l}\text { answered Lord } \\
\text { Henry, }\end{array}$ & $\begin{array}{l}\text { laying his hand } \\
\text { upon his shoulder; }\end{array}$ & $\begin{array}{l}\text { 'not at all, my } \\
\text { dear Basil.' }\end{array}$ \\
\hline JR & - Não - & $\begin{array}{l}\text { respondeu lorde } \\
\text { Henry }\end{array}$ & Omission & $\begin{array}{l}\text { - absolutamente, } \\
\text { meu caro Basil. }\end{array}$ \\
\hline LIS & $\begin{array}{l}\text { - Pelo contrário, } \\
\text { Basil! }\end{array}$ & Omission & Omission & Omission \\
\hline LOP & - De jeito nenhum & $\begin{array}{l}\text { respondeu Lorde } \\
\text { Henry -, }\end{array}$ & Omission & $\begin{array}{l}\text { de jeito nenhum, } \\
\text { meu querido Basil. }\end{array}$ \\
\hline
\end{tabular}

If we compare excerpts 4 and 5, we will see two identical logical constructions of the experiential type: walking across the studio towards Basil Hallward (excerpt 4) and laying his hand upon his shoulder (excerpt 5). Both are expansions, more precisely hypotactic structures of enhancement. ${ }^{12}$ Nevertheless, while in excerpt 4 the hypotaxis comprehends only a specific action performed by the character, in excerpt 5 , besides playing a likely semantic role, it also expresses a kind of affection (behavioral) towards one of the characters, Basil Hallward. Both hypotaxes qualify the quantum of saying with some sort of circumstantial feature, but only in excerpt 5 do we observe that it construes a kind of affection, in this case, of behavior (cf. MARTIN; WHITE, 2005, p. 46). Expansions serve different narrative interests, but in the case of the data analyzed in the present study, it is one of the means of revealing some traits of femininity usually attributed to the characters. This specific discourse event, linguistically represented by the expansion, is completely lost in the translation and adaptations.

Excerpt 6:

\begin{tabular}{|l|l|l|l|}
\hline OW & $\begin{array}{l}\text { 'I hate the way you talk about } \\
\text { your married life, Harry, }\end{array}$ & $\begin{array}{l}\text { said Basil } \\
\text { Hallward, }\end{array}$ & $\begin{array}{l}\text { shaking his hand off, and strolling towards } \\
\text { the door that led into the garden. }\end{array}$ \\
\hline JR & $\begin{array}{l}\text { - Não gosto desse teu sistema } \\
\text { de falar de tua vida conjugal, }\end{array}$ & $\begin{array}{l}\text { disse Basil } \\
\text { Hallward, }\end{array}$ & $\begin{array}{l}\text { [omission] dirigindo-se para a porta } \\
\text { que abria sobre o jardim. }\end{array}$ \\
\hline LIS & $\begin{array}{l}\text { - Detesto esse seu modo de } \\
\text { falar da sua vida conjugal, } \\
\text { Henry. }\end{array}$ & Omission & Omission \\
\hline LOP & $\begin{array}{l}\text { - Odeio o jeito como você fala } \\
\text { de sua vida de casado, Harry - }\end{array}$ & disse Basil, & $\begin{array}{l}\text { [omission] caminhando em direção à } \\
\text { porta que dava para o jardim. }\end{array}$ \\
\hline
\end{tabular}

${ }^{12}$ A subordinate clause that 'embellishes' the main clause by enhancing it (see footnote 5). 
In excerpt 6, the projected clauses show, to a certain extent, equivalence in meaning, given that both the translated and the adapted versions unpack similar semantic constructions, i.e., either the original text or the translations express affective evaluations of dissatisfaction in the projected clauses. When we turn to projecting verbs and Sayers, however, it is noticeable that JR translated the original literally, whereas LOP has chosen name abbreviation and LIS has simply omitted this part. Perhaps this choice is due to the kind of reader LOP had in mind (juvenile readers), in whose communities of practice $^{13}$ abbreviations, nicknames, and the like are used to interact and create identities. Nevertheless, this would only make sense if LOP followed this lexical pattern throughout her translation, which has not happened (see, for instance, the lexical choice Lorde Henry, in excerpt 5). It is thus clear that LOP has not taken a specific translation strategy to convey the original, which leads us to hypothesize that her work was based upon free decisions of what to translate and how to translate it.

Concerning appraisal, differences become quite obvious when we turn to the following hypotactic structure in nesting position: ${ }^{14}$ shaking his hand off, and strolling towards the door that led into the garden. In this clause complex, the narrator judges the character's 'normality', ${ }^{15}$ imposing upon it a burden of gay femininity. This is particularly noticeable by the use of shake off, as if forcing a passage, and stroll, a material process denoting a particular manner of gay walk. OW has chosen this very specific material process, stroll, as one of the various linguistic means he used in the novel to hint at characters' behaviors, more specifically, their gayness. This linguistic choice helps readers

${ }^{13}$ Communities of practice is a concept introduced by Lave and Wenger (1991) whose definition lies on the notion of participation within social practices that are typical of specific communities. Wenger expands the concept by claiming that "participation (...) refers (...) to a more encompassing process of being active participants in the practices of social communities and constructing identities in relation to these communities" (1998, p. 4). This is the idea we have in mind when we refer to 'gay communities'.

${ }^{14}$ In the clause complex, this takes on the meaning of an internal bracketing; in the example, we have a bracket represented by the connective 'and': shaking his hand off [and] strolling towards the door. It means that the character is performing two actions concomitantly and not one at a time (cf. HALLIDAY, 1994, p. 217-224).

15 This evaluative source falls within the social esteem type, referring to "normality" (how unusual someone is)" (MARTIN; WHITE, 2005, p. 52-53). 
to identify some of the personality traits assigned to the characters, opening space for what is known as gaydar ${ }^{16}$ (cf. ZWICKY, 1997), that is, the ability to identify homosexual characteristics in people. Although the novel carries a variety of lexicogrammatical constructions that locate the characters within the edges of gay community lifestyles, the semantic effects of these verbal choices have simply been left out of the translated and adapted versions. Instead, the translators have chosen verbs like dirigindo-se (heading) and caminhando (walking), in addition to having deliberately omitted the semantic construction of the character when the narrator chose the process shake off to refer to a specific behavior of Basil Hallward.

Excerpt 7:

\begin{tabular}{|l|l|l|l|}
\hline OW & $\begin{array}{l}\text { 'Being natural is simply a pose, and } \\
\text { the most irritating pose I know,' }\end{array}$ & cried Lord Henry, & laughing. \\
\hline JR & $\begin{array}{l}\text { - Ser natural é também uma afetação } \\
\text { e a mais irritante que eu conheço - }\end{array}$ & $\begin{array}{l}\text { exclamou, rindo, } \\
\text { lorde Henry. }\end{array}$ & [shifted] \\
\hline LIS & $\begin{array}{l}\text { - Ser natural já é uma pose, a mais } \\
\text { irritante que conheço - }\end{array}$ & acrescentou lorde Henry & jovialmente. \\
\hline LOP & $\begin{array}{l}\text { - Ser natural é simplesmente uma } \\
\text { pose, e a mais irritante que conheço }\end{array}$ & respondeu Lorde Henry, & rindo. \\
\hline
\end{tabular}

Excerpt 7 has several linguistic choices that denote appraisal. The evaluative axis lies in the verbal process $c r y$. By having chosen this process to represent the narrator's point of view, OW has imposed on it the figure of a person using a sharp tone of voice, typical of gay talk. JR has chosen, with some success, the verbal process exclamou (exclaimed) as a possible equivalent for $c r y$; but LIS and LOP have not reached the same result when choosing the verbs acrescentou (added) and respondeu (answered/replied), respectively, to express the same meaning of the original choice.

The use of cry, together with the hypotaxis laughing, gives the semantic contour of happiness (effect of the happiness sort), expressed in the exotic way Lord Henry has positioned himself against Basil Hallward's behavior. It is curious, however, that LIS has completely changed the meaning of laughing, by instead choosing the modal adjunct jovialmente (genially), in Portuguese.

\footnotetext{
${ }^{16}$ The combination of two words, gay and radar, a colloquialism that represents the ability some people have to identify sexual orientation in others.
} 
In addition to rupturing the logical hypotactic construction, by translating the hypotaxis into an adjunct, jovialmente forms a misleading picture in terms of the meaning provided by laughing. That is, it only expresses a person who is happy and friendly, and not a person who feels an exquisite pleasure for having given such a brilliant and dissenting opinion on moral edicts.

The finite linguistic construction Being natural is another decision for assessment, in this case a kind of social sanction representing how someone should behave in front of others, in order to build social rapport. Hence, Lord Henry is negatively judging Basil Hallward's behavior concerning ethics and morality. There is, indeed, an inversion of opinions in his speech, because what Lord Henry considers unethical is actually what someone is supposed to do according to social rules of etiquette. This is clearly seen when the character chooses the noun pose to refer to a wrong attitude adopted by Basil Hallward. What is interesting here is the use of the words afetação and pose, in the translations, for pose, from the original. While JR has rendered the original word as afetação, LIS and LOP have translated it as pose.

The noun afetação seemed to be purposely chosen by JR, because he was a dandy who contributed to the dissemination of what we call 'the late French belle époque in Rio de Janeiro' (cf. FIGARI, 2007) and, consequently, knew the impacts this kind of word choice would exert on (gay) readers. As a member of a gay community that was not quite so open as it is nowadays, JR translated Oscar Wilde with an aim in mind: to give visibility to the embellishments of a novel which left its distinguishing mark on the history of modern literature as well as on the Victorian period. It is clear then that JR has put too much effort into this work, in an attempt to bring to light the fascinating world of elegance, perversity, and gayness, a tripartite feature that pervades the entire plot. One important tool JR had to help him fulfill his aim was word choice. ${ }^{17}$ Afetação is a case in point, since, for a lay reader ${ }_{2}$ it is no less than a kind of unnatural and offensive action; for a gay reader, however, it encompasses a wide range of meanings often related to a gay person who, besides being extravagant, is effeminate, exaggerated, and sometimes

\footnotetext{
${ }^{17}$ The concept of choice lies in the fundamentals of Systemic-Functional Linguistics; i.e. the speaker/writer chooses a word, in detriment of a finitude of several other words that comprise the system of the language being used, in an attempt to convey the meaning she/he has in mind. This linguistic system is also known as meaning potential (cf. HALLIDAY; MATTHIESSEN, 2004, p. 19-31).
} 
hysterical. ${ }^{18}$ This marked word choice expands opportunities for multiple interpretations on the part of gay readers, since it creates a very clear picture of a person who is effeminate and sometimes cannot handle tough situations without running afoul of the limits of 'gay etiquette'.

In the case of LIS and LOP, the noun pose is a synonym for artificiality and affectation, different from the impacts of the meaning of afetação on a Brazilian gay reader. Both choices, pose or afetação, have ideological reasonings. In the case of the adaptations, LIS and LOP kept a very clear reader in mind: adolescents. This characteristic has most likely imposed some cuts and maneuvers on the part of the translators (advised, of course, by the Editors), especially if we take the historical time of each adaptation. LIS's translation was originally published in 1974, a period in which Brazilian society was still struggling with the bitter legacies of a dictatorial government. In the case of LOP's translation, originally rendered in 1997, Brazil was suffering the deadly consequences of what Trevisan (2004) calls 'the gay plague', a metonym for AIDS. In the case of JR's translation, the effervescent cultural context in 1919, two years before the most famous literary and artistic event in Brazil, the Week of Modern Art (Semana de Arte Moderna), has given him large leeway to recreate the multilayered dandyism (and gayness) lifestyle in Rio de Janeiro through OW's novel.

Excerpt 8:

\begin{tabular}{|l|l|l|l|}
\hline OW & 'I will tell you', & said Hallward; & $\begin{array}{l}\text { and an expression of perplexity } \\
\text { came over his face. }\end{array}$ \\
\hline JR & - Eu te contarei - & respondeu Hallward & sombriamente. \\
\hline LIS & Omitted & Omitted & Omitted \\
\hline LOP & Omitted & Omitted & Omitted \\
\hline
\end{tabular}

Two important aspects in excerpt 8 that merit consideration are the translation choice sombriamente (effect of the quality sort) and the omissions in both adapted versions. Let us begin with the omissions. The striking feature in this respect is the complete lack of correspondence between the message conveyed by the original and the omissions. That is, the experiential aspect of

${ }^{18}$ For an interesting article on this issue, access http://grisalhos.wordpress.com/ 2011/11/07/o-gay-afetado-e-o-masculino/. 
the novel in this section has simply been omitted, leaving it unknown to the reader. It is difficult to infer the whys and wherefores of the omissions, unless we query the translators themselves about them. Since it goes beyond the scope of this paper, we rely on the fact that, according to Munday (2008), patterns of choice have to do with translators' styles and voices: "Other phenomena which show the translator's presence are omissions [...], rewriting, or summarizing" (Id. Ibid., p. 15).

In the instance of JR's choice for sombriamente (lugubriously), this shows a clear case of rewriting. The original brings a whole paratactic construction, initiated by the conjunction and, to express the narrator's description of the way Basil Hallward expressed himself when he told Lord Henry about his decision to keep the portrait private. Perplexity is the central evaluative aspect revealed in the paratactic structure; nonetheless, JR has neglected this aspect and has instead chosen the modal adjunct sombriamente in order to embrace the entire structure in one single term.

In this respect, two aspects should be considered. First, concerning linguistic construction, the choice for sombriamente indicates a pair of two extremes: at one extreme we have literal correspondence, while at the other we have free rewriting. JR has decided to interpret the semantic contours of the parataxis and an expression of perplexity came over his face rendering it as sombriamente, an adjunct that means, in Brazilian Portuguese, 'disgracefully', 'desperately', 'severely', 'lugubriously', and the like. Second, the intended meaning conveyed by JR's choice has provided a very different idea of what Basil Hallward was actually feeling, of his reaction towards the situation in which he was placed. Brazilian readers would interpret Basil's feelings as someone who is not perplexed, but behaving weirdly, as if devising a plan or a witty remark. As a consequence, in excerpt 8, the discourse event created in the original text is somewhat lost in the translation.

Excerpt 9:

\begin{tabular}{|l|l|l|l|}
\hline OW & 'I am all expectation, Basil, & murmured his companion; & looking at him. \\
\hline JJR & - Sou todo ouvidos, Basil. & Omitted & Omitted \\
\hline LIS & Omitted & Omitted & Omitted \\
\hline LOP & Omitted & Omitted & Omitted \\
\hline
\end{tabular}


In excerpt 9, the experiential picture is of two characters, Basil Hallward and Lord Henry, in which the latter is querying the former whether he will explain the reasons for not exposing the portrait. The discourse event then is of two people who are, on the one hand, trying to uncover a secret (Henry) and, on the other hand, gathering courage to reveal it (Basil). Moreover, the verbal process murmured attaches an underlying meaning to the interaction: Lord Henry expresses himself in a soft quiet voice, ${ }^{19}$ which creates a picture of someone who is trying to manipulate Basil Hallward's feelings, as if soothing him in order to encourage him to speak. This image is supported by the expansion looking at him, which allows us to say that the verbal process murmur is at the edge of verbal and behavioral linguistic experiences. In this case, Lord Henry either expresses himself verbally or behaves in a way that is clearly seen by the choice of murmur.

Another intriguing linguistic choice is his companion, a very clear proof of the indirect evaluative presence of the narrator. That is, the narrator is nominating the Sayer, investing him with the characteristics of a partner. In other words, companion gives the idea of someone who is more than a friend; indeed, it is someone who spends a lot of time with a very close friend. This marked word choice also points to a kind of person with whom someone has a long-term sexual partnership, usually outside marriage. ${ }^{20}$ In this very particular case, the narrator aligns the putative (gay) reader with the character's identity, in a bid to engage the reader in that dialogical scene.

OW's choices have undoubtedly struck a chord with a wide range of social practices of dandyism as well as the homosexuality that pervaded most of the extra-marital relationships at the time the novel was written. Even though JR's translation renders the projected clause Sou todo ouvidos, Basil, it totally omits the discourse event conveyed by the verbal process murmured. In the case of LIS's and LOP's adaptations, the discourse event is omitted altogether, whose decision leads us to consider that their translation strategy is more tuned to rewriting or free translation.

\footnotetext{
${ }^{19}$ According to the 8th edition of the Oxford Advanced Learner's Dictionary.

${ }^{20}$ According to the New Oxford American Dictionary.
} 
Excerpt 10:

\begin{tabular}{|l|l|l|l|l|l|}
\hline OW & $\begin{array}{l}\text { Lord Henry smiled, } \\
\text { and, leaning down, } \\
\text { plucked apink-petalled } \\
\text { daisy from the grass, } \\
\text { and examined it. }\end{array}$ & $\begin{array}{l}\text { 'I am quite } \\
\text { sure I shall } \\
\text { understand it, }\end{array}$ & he replied, & $\begin{array}{l}\text { gazing intently } \\
\text { at the little } \\
\text { golden white- } \\
\text { feathered disk, }\end{array}$ & $\begin{array}{l}\text { and I can believe } \\
\text { 'anything, } \\
\text { provided that } \\
\text { it is incredible.' }\end{array}$ \\
\hline JR & Omitted & $\begin{array}{l}\text { - Estou bem } \\
\text { certo de que } \\
\text { compreenderei }\end{array}$ & $\begin{array}{l}\text { afirmou } \\
\text { ele, }\end{array}$ & $\begin{array}{l}\text { olhando } \\
\text { atentamente o } \\
\text { o discozinho } \\
\text { dourado, de } \\
\text { pétalas brancas. }\end{array}$ & $\begin{array}{l}\text { E, quanto a crer } \\
\text { nas coisas, eu creio } \\
\text { em todas elas, } \\
\text { desde que sejam } \\
\text { incríveis. }\end{array}$ \\
\hline LIS & Omitted & $\begin{array}{l}\text { - Estou certo de } \\
\text { que o entenderei. }\end{array}$ & Omitted & Omitted & $\begin{array}{l}\text { Quanto a acreditar, } \\
\text { sou capaz de } \\
\text { acreditar em tudo, } \\
\text { desde que seja coisa } \\
\text { absolutamente } \\
\text { incrível. }\end{array}$ \\
\hline LOP & Omitted & Omitted & Omitted & Omitted & Omitted \\
\hline
\end{tabular}

In excerpt 10 , the evaluative scene construed is that of the appreciation type. Nonetheless, it is not only perceived by the use of the modal adjunct intently or through the word choices Lord Henry pronounces, such as quite sure (graduation: force) and incredible (appreciation: reaction). Actually, the narrator's point of view reveals the picture of a character who is providing a semantically graded appreciative contour to the event, present in the way the narrator embellishes the discourse event in a garden, appreciating daisies - and choosing words that express Lord Henry's insatiable curiosity about the complex subject he and Basil Hallward were discussing. The scenario faithfully represents the Victorian estheticism, "defined as the perception or appreciation of beauty" (PURCHASE, 2006, p. 37). ${ }^{21}$

The evaluative scene described in the original is partially lost in JR's translation. The translator deliberately omitted the first part of the scene, hindering the Brazilian (gay) reader from unpacking the whole scenario of the discourse event. By only emphasizing that Lord Henry was looking at a 'little golden disk of pink

\footnotetext{
${ }^{21}$ Purchase (2006) also refers to decadence, as "moral, cultural or sexual degeneration", pointing out that the concepts of decadence and estheticism, in the context of Victorian literature, "are often best understood together, and certainly with the rise of the Oscar Wilde circle in 1890s they became interchangeable" (p. 37).
} 
petals' (discozinho dourado, de pétalas brancas), JR has lost the aesthetic background of the message, considerably diminishing the appreciative force of the typical scenario of dandyism, fairly common at the time the novel was written. In addition, JR translated pink (in Brazilian Portuguese, rosa) for branca (white), depicting a slight different discourse event compared to the original, especially if we consider that pink color is usually associated with dandyism.

LIS's adaptation has partially covered the semantic constructions of the scene, for she only translated the projecting clauses of the original. As a tentative linguistic strategy to remedy this loss, LIS has added the modal adjunct absolutamente (absolutely, quite) in order to give emphasis to incrivel (incredible). But, even trying this, the original discourse event is completely lost. Needless to say, this part has vanished in LOP's adaptation, which points to a kind of manipulation of the message intended for the juvenile reader.

\section{Concluding remarks}

In this paper, we have attempted to explore how the System of Appraisal can help uncover subtle features of discourse events in literary texts. The notion of discourse event has proven to be very useful for the purposes of this study, because it has given us a clearer idea of the important role the narrator played for the linguistic construction of characters. In fact, the analyses have indicated that the vast majority of linguistic descriptions of femininity were offered by the narrator, which points to the importance of narrative point of view to construe the plot and to establish ideological standpoints. The linguistic resources of evaluation used to outline this scenario were mostly modal adjuncts and expansions, which focused on the description of characters' feelings, emotions, and behaviors.

The analyses have revealed that the linguistic resources of appraisal carry different meanings in each language and, consequently, in each text (original, complete translation and adaptations). If we take the discourse events of each passage, we will see that their descriptions help clarify the subtle meanings of evaluation intended by OW, especially through the narrative point of view. This aspect can be clearly perceived, for instance, in the analyses of excerpts 7 , 9 , and 10, by the uses of verbal processes cry and murmur, and the expansion smiled, and, leaning down, plucked..., respectively. In terms of lexicogrammar (HALLIDAY; MATTHIESSEN, 2004), these constructions reveal specific semantic contours of evaluation in English, which was not accurately captured in the translations. In the case of the verbal process cry, however, JR tried to express the idea surrounding this semantic construction by choosing the verb 
exclamou (exclaimed) ${ }_{2}$ accompanied by the modal adjunct rindo (laughing); LIS and LOP, on the other hand, chose the verbal processes acrescentou (added) and respondeu (answered/replied), respectively, without any attempt to capture the evaluative burden of cried. In terms of lexical choices, the noun afetação (pose) is a case in point. In this example (excerpt 7), the discourse event of the passage is a very important resource to uncover the real meaning of this word intended by OW, which was, in our interpretation, successfully captured by JR. The assumptions underlying the analyses show that appraisal is both cultural-laden and based on a wide range of interpretations on the part of the receiver of the message. In this aspect, Martin and White express that:

(...) we do not see textual instances as the end point of instantiation. While texts are often highly constraining in terms of the meanings which are to be taken up, it is, nevertheless, only through the act of reader/ listener interpretation in a given context that meaning actually occurs. And this final 'reading' may, of course, vary between readers/listeners according to the assumptions, knowledge and value systems they bring to the text and the use they are making of the text (2005, p. 162-163).

We therefore consider that Appraisal is a powerful resource to understand how individuals construe realities by means of language, located in different contexts and cultures, and how discourses play a huge part for the creation of meanings in multiple social events.

The discussion has also shown several differences of evaluative linguistic choices in the translations when compared to the original. These differences have demonstrated that the analyzed corpora do not fall within the boundaries of a strict linguistic correspondence, but rather within the limits of text recreation or rewriting, regardless of whether it is a complete translation or an adapted version. This aspect is, to a certain extent, puzzling, since it questions the general view of adaptations as distortions or falsifications (cf. BASTIN, 1998), although we are not affirming that adaptations do not hold distinguishing characteristics when compared with other types of translation. In this respect, we agree with Yallop (2001, p. 242) when he claims that:

equivalence is not a relationship that is fixed once and for all, and the question is (...) what kind of similarity we are prepared to accept as equivalence in a particular context for a particular purpose. Equivalence is constructed, not out of absolute identity but out of a rich diversity of similarities. 
All in all, this paper has shed light on some aspects of translation that deserve further investigation, more specifically how translations should be understood primarily as rewritings, especially within a context in which controversial discourses of prejudice and censorship are at stake.

\section{References}

BASTIN, G. L. Adaptation. In: BAKER, M. (Org.). Routledge Encyclopedia of Translation Studies. London \& New York: Routledge, 1997. p. 5-8.

FIGARI, C. @s Outr@s Cariocas: Interpelaçōes, experiências e identidades homoeróticas no Rio de Janeiro Séculos XVII ao XX. Belo Horizonte: Editora UFMG/Rio de Janeiro: IUPERJ, 2007.

HALLIDAY, M. A. K. An Introduction to Functional Grammar. London: Edward Arnold, 1985.

HALLIDAY, M. A. K. An Introduction to Functional Grammar. 2. ed. London: Edward Arnold, 1994.

HALLIDAY, M. A. K.; MATTHIESSEN, C. M. I. M. An Introduction to Functional Grammar. 3. ed. edn. London: Edward Arnold, 2004.

HARVEY, K. Gay Community, Gay Identity and the Translated Text. Traduction Terminologie Rédaction: Études sur le Texte et ses Transformations,v. 13, n. 2, p. 137-165, 2000a.

HARVEY, K. Translating the Queens' English: Parodic Femininity in Fictional Representations of Gay Talk: A Study of French Representations of Late American Gay Fiction. Unpublished Dissertation. Manchester, UK: UMIST, 2000b.

HUNSTON, S.; THOMPSON, G. (Org.). Evaluation in Text: Authorial Stance and the Construction of Discourse. Oxford: Oxford University Press, 1999.

JAWORSKI, A.; COUPLAND, N. Introduction: Perspectives on Discourse Analysis. In: JAWORSKI, A.; COUPLAND, N. (Org.). The Discourse Reader. 2. ed. London; New York: Routledge, 2006. p. 1-37.

KUSHNER, T. Angels in America, Part One: Millennium Approaches. London: Royal National Theatre and Nick Hearn Books, 1992.

LAVE, J.; WENGER, E. Situated Learning: Legitimate Peripheral Participation. Cambridge University Press, 1991.

MARTIN, J. R. English Text: System and Structure. Philadelphia; Amsterdam: John Benjamins, 1992. 
MARTIN, J. R. Beyond Exchange: Appraisal Systems in English. In: HUNSTON, S.; THOMPSON, G. (Org.). Evaluation in Text: Authorial Stance and the Construction of Discourse. Oxford: Oxford University Press, 1999. p. 142-175. MARTIN, J. R.; ROSE, D. Working with Discourse: Meaning beyond the Clause. London; New York: Continuum, 2003.

MARTIN, J. R.; ROSE, D. Working with Discourse: Meaning beyond the Clause. 2. ed. London; New York: Continuum, 2007.

MARTIN, J. R.; WHITE, P. R. R. The Language of Evaluation: Appraisal in English. New York; UK: Palgrave, 2005.

MATTHIESSEN, C. M. I. M.; TERUYA, K.; LAM, M. Key Terms in Systemic Functional Linguistics. London; New York: Continuum, 2010.

MIGHALL, R. Introduction. In: WILDE, O. The Picture of Dorian Gray. London; New York: Penguin Books, 2003. p. ix-xxxiv.

MUNDAY, J. Style and Ideology in Translation: Latin American Writing in English. London; New York: Routledge, 2008.

PIRES, E. C. R. Oscar Wilde: A Tragicidade da Vida de um Escritor. Bragança, Portugal: Instituto Politécnico de Bragança, 2005.

PURCHASE, S. Key Concepts in Victorian Literature. New York; UK: Palgrave, 2006.

SCHIFFLER, D. S. Oscar Wilde. Trad. Joana Canêdo. Porto Alegre, RS: LP\&M, 2010.

SIMPSON, P. Language, Ideology and Point of View. London; New York: Routledge, 1993.

TREVISAN, J. S. Devassos no Paraíso: A Homossexualidade no Brasil, da Colônia à Atualidade. 6. ed. Rio de Janeiro: Record, 2004.

WENGER, E. Communities of Practice: Learning, Meaning, and Identity. Cambridge: Cambridge University Press, 1998.

YALLOP, C. The Construction of Equivalence. In: STEINER, E.; YALLOP, C. (Org.). Exploring Translation and Multilingual Text Production: Beyond Content. Berlin; New York: Mouton de Gruyter, 2001. p. 229-246.

ZWICKY, A. M. Two Lavender Issues for Linguistics. In: LIVIA, A.; HALL, K. (Org.). Queerly Phrased: Language, Gender, and Sexuality. Oxford: Oxford University Press, 1997, p. 21-34.

Recebido em 20/08/2012. Aprovado em 17/12/2012. 